\title{
Integration of Local Wisdom Values of Seren Taun Traditional Ceremony in Social Science Lesson as Learning Model of Ethnopedagogy in SMPN 1 Nagrak District of Nagrak Regency of Sukabumi
}

\author{
Endang Komara, Professor of Social Sciences at Education Master Program in STKIP Pasundan, \\ endang_komara@yahoo.co.id \\ Yudikusyadi , Lecture at the Study Program of Civic Education STKIP Pasundan, yudi.kusyadi@gmail.com \\ Neneng Meliyani , Teacher of SDN 3 Nagrak Sukabumi, nenengmeliyani82@gmail.com
}

\begin{abstract}
Integration of local wisdom values in social science lesson is one of the effort to strengthen national identity of young generations who have disappeared because of strong globalization. One of them is the integration of local wisdom values of Seren Taun traditional ceremony as a model of Ethnopedagogy. The approach of research uses qualitative approach with the case study method. The result of research showed: First, the form of local wisdom values of Seren Taun traditional ceremony found in the meaning of expressions and proverbs used by Kasepuhan Ciptagelar people is: (a) Ngajagi Tatali Paranti Karuhun (Religious Value), (b) Nincak Kana Tatanan (Compliance Value), (c) Nangtung di kariungan ngadeg di karamean (Mutual Aid Value), (d) Gunung luhur kayuan, lamping gawir awian, legok balongan, lebak kulahan, datar sawahan (Conservation Value of Natural Resources), (e) Saiketan Sabeungkeutan (Associations and Unions Values), (f) Kudu bisa ngigelan jaman tapi ulah kabawa ku jaman (Balance Value Between Tradition and Modernization). Second, the integration of local wisdom values in traditional ceremony of Seren Taun Kasepuhan Ciptagelar in social studies lesson by developing syllabus and preparing Learning Implementation Plans (RPP). Third, the implementation of social studies with the ethnopedagogy model is able to attract attention of students in understanding the values of local wisdom as the national identity. Ethnopedagogy models will be more effective if it is implemented with strategies within an innovative learning media. Actualization of learning that is oriented to instilling the values of local wisdom is often followed by playing activities so as to create active, creative, effective, and fun learning and can foster a love of national culture.
\end{abstract}

Keywords: Local wisdom values, Seren Taun, social studies, ethnopedagogy.

Received: 04.12.2020 Accepted: 25.01.2021 $\quad$ Published: 06.02.2021

\section{INTRODUCTION}

Indonesia is a multicultural country, because it was built by hundreds of ethnic groups with different cultural backgrounds from one another. The plurality of Indonesian society is not only formed because of its ethnic diversity, but also because of differences in cultural backgrounds, history, religion and belief systems, as well as the condition of its geographical environment. However, even though the Indonesian nation is full of differences, they still maintain mutual harmony within the framework of "Bhinneka Tunggal Ika" (Unity in Diversity). This is inseparable from the nature of humans as social beings. Humans are creatures that live socially, interact one another and cannot live alone. According to Yesmil Anwar and Adang (2017: 169) that "the human instinct to always live and relate to other people is called 'gregariousness' and therefore humans are called social beings". With this instinct, man develops his knowledge to transcend his life and give meaning to his life. Because when compared to other creatures in this world, humans have limitations in terms of organisms. To overcome the limitations of these organisms, humans develop systems in their lives through their intellect and minds such as developing communication systems, kinship systems, livelihood systems, living equipment systems and other systems that aim to sustain life. In living their lives, humans will always be together and always depend on other humans.

The main characteristic of social beings is cultured life. In other words, live using common sense in a value system that applies within a certain period of time. Cultural life includes a philosophy consisting of a view of life, politics, technology, communication, economy, social, culture and security. Thus, humans are known as cultured creatures because humans' function as culture-forming as well as can play a role because they are driven by the desires or wishes that exist within humans themselves. 
Budaya (culture in Indonesian language) comes from the Sanskrit language, namely buddhayah, which is the plural form of buddhi (mind or intellect); interpreted as matters relating to human mind and intellect. Another form of the word budaya is kultur which comes from English, namely culture and Latin cultura. The form of culture includes, first, ideas or notion in the form of: norms, customary law, knowledge. Second, behavior (patterned); livelihoods, beliefs, traditional ceremonies / rites, daily habits, traditional institutions, social organizations, the arts. The third is the result of human behavior, in the form of historical and ancient relics, traditional food, folk games, crafts, ancient manuscripts, and artefactual.

The meaning of culture according to Koentjaraningrat in Sulasman and Gumilar (2018: 19) that states, "Culture is the result of human thinking, feeling and intention in the context of community life which is made the property of humans by learning." Bakker in Munandar Sulaeman (2018: 41) explains that "culture as the creation and development of value includes everything that is in the physical, personal and social, which is made perfect for the realization of human and community energy." In the cultural definition expressed by Bakker, it deals with the problem of value creation in culture itself. The cultural value system in society is an abstraction from customs which is the concept of what lives in the minds of citizens of a community. So, in general, culture is the result of human thinking, feeling and intention in fulfilling their complex life needs which include knowledge, belief, art, morals, customary law and every skill and habit. It can also be interpreted as anything complex, which contains art, beliefs, knowledge, law, morals, customs and expertise or other characteristics acquired by individuals as members of a society.

One form of culture is local wisdom. Local wisdom is a value system or life behavior of local people in interacting wisely with the environment in which they live. According to A. Chaedar Alwasilah et al (2009: 51) that "local wisdom is the process of how knowledge is generated, stored, applied, managed and inherited." Meanwhile, Wibowo (2015: 17) argues that "Local wisdom is the identity or cultural personality of a nation which causes the nation to be able to absorb, even cultivate culture originating from outside / other nations into its own character and abilities." The identity and personality certainly adjusted to the view of life of the surrounding community so there is no shift in values. Indonesia is a country that rich in ethnic groups, each of which has a culture as their ethnic identity. The Indonesian nation has many values of local wisdom inherent in everyday life which have been preserved from generation to generation, especially in the lives of indigenous peoples.

The indigenous peoples who still exist today are scattered in various regions in Indonesia, one of which is the Kasepuhan Ciptagelar indigenous people, namely groups of people who still adhere to the cultural heritage of their ancestors in carrying out their daily lives. The Kasepuhan Ciptagelar indigenous people are in Sukamulya Hamlet, Sirnaresmi Village, Cisolok District, Sukabumi Regency, which are members of the South Banten Custom Kasepuhan. They really respect and appreciate culture as a result of the thinking, feeling and intention of their ancestors. They believe that the culture inherited is a rule that must be obeyed to regulate the order of life so that it runs in conformable, harmony and leads to goodness. One example of a culture that is held firmly by the people of the Kasepuhan Ciptagelar Traditional Village is in protecting, appreciating and loving nature, and as evidence of their love for the surrounding nature is clearly illustrated in the Seren Taun traditional ceremony. The term Seren Taun comes from the Sundanese seren which means "hand over, give each other or to deliver", and taun which means "year". So, the meaning of the Seren Taun tradition is the handover of crops in the form of rice from the previous year to the next year as a substitute. The rice from the harvest is stored in the leuit (rice barn). Basically, the Seren Taun traditional ceremony ritual is a form of gratitude to the Creator for all agricultural products this year, hoping that their agricultural product will increase in the coming year, as well as a medium for praying so that everything they do will be blessed and in accordance to God's will. They believe that by using the methods inherited from their ancestors, the harvest will be abundant and the most believed is the blessing that is in the harvest. All residents are involved in the series of Seren Taun traditional ceremonies both in mind, energy, and even materially. They work hand in hand and work together according to their respective duties for the success of the Seren Taun event. For the people of Kasepuhan Ciptagelar Traditional Village, Seren Taun is very sacred and they believe that involvement in Seren Taun is an obligation that must be fulfilled. Until now, the people of Kasepuhan Ciptagelar Traditional Village still maintain and conserve their ancestral heritage, namely the view of life that is actually hidden behind the behavior of their daily life. This view of life makes them a strong community in maintaining and conserving local wisdom values in family life and social life, so that they can live in harmony, safety, and peace.

Along with the reverberation of globalization, people all over the world, including the Indonesian nation, must be ready to accept outside influences on various aspects of the nation's life. One of the aspects that has been most strongly affected is culture. The resilience of local culture is currently being tested in the face of the global penetration of foreign cultures that have a strong influence on the life order 
of the world community. A world that seems limitless as a consequence of globalization, encourages people to unite as a world community who can interact and be connected at any time through sophisticated communication tools. But the implications of this association can erode the values of local culture so that the culture that has been embedded since the time of their ancestors will gradually be uprooted by the strong influence of foreign cultures. Foreign culture can weaken national identity, especially among teenagers.

The role of education is very important in overcoming social problems. Exploring and applying local wisdom values through education is an effort that can be taken to build national character, strengthen national identity and serve as a filter for the selection of foreign cultures that are increasingly hitting almost all aspects of life. As stated by Kartadinata (in his introduction to the Ethnopedagogy Book by Chaedar Alwasilah et al., 2009) that "we have been dazzled by the Western education system, so we are blind to the local excellence that has long been buried in the earth of Indonesian culture .... Universitas Pendidikan Indonesia then responded with its idea, namely ethnopedagogy." Ethnopedagogy is an educational practice based on local wisdom. Still according to Chaedar Alwasilah et al (2009: 69) that "education based on local wisdom through ethnopedagogy will provide meaningful enrichment to support the goals of national education which is Indonesia." Thus, the integration of local wisdom values in education will help shape the character of students who are virtuous, respect their own culture, foster a sense of love for the country and are proud of their identity as the Indonesian nation.

\section{THEORETICAL FRAMEWORK}

\section{Local Wisdom Values}

Local wisdom seen from its etymological aspect consists of two words, namely wisdom and local. Local wisdom is the views of the local community that are wise, full of wisdom and have values and norms that are believed to be true, then embedded and followed by all members of the community and become a reference in their daily actions and behavior. In the discipline of anthropology, the term local genius is known. Local Wisdom, which is a translation of "Local Genius" was introduced by Quaritch Wales in 19481949 with the meaning "The ability of local culture to deal with foreign cultural influences when the two cultures were connected, (Rosidi, 2011: 29)." Based on the definition of local wisdom according to Quaritch Wales, it is very appropriate considering the beginning of the era of globalization where cultural acculturation is a sure thing to happen. Cultures from all over the world are interconnected. Besides being positive, there are also negative influences that it carries. Therefore, it is necessary to have the ability of local culture to be able to minimize the negative influence of foreign culture brought by citizens from various parts of the world, either directly or indirectly, especially against negative influences that will damage the personality of the Indonesian people. The rapid development of social media is marked by the increasing level of human activity in cyberspace and contributing to foreign cultural influences on local residents. Local wisdom is considered capable of being a bulwark against attacks by foreign cultural influences that are incompatible with the character and identity of the Indonesian nation. According to Haryati Soebadio in Rohaedi (1986: 18) that: Local wisdom is the identity or cultural personality of a nation which causes the nation to be able to absorb, even process culture from outside / other nations into its own character and abilities.

This identity and personality naturally adjust to the view of life of the surrounding community so that there is no shift in values. Local wisdom can be seen as the identity of the nation, especially in the context of Indonesia which allows local wisdom to be transformed across cultures which in turn creates national cultural values.

Law No. 32 of 2009 concerning Environmental Protection and Management, provides an understanding of local wisdom, namely 'the noble values that apply in the order of community life, among others, to protect and manage the environment in a sustainable manner.' Therefore, local wisdom that develops in life society is a form of civilization inheritance that is carried out continuously from generation to generation. This local wisdom can be said to be an example of culture in Indonesia that provides values and norms in human life. Local wisdom is one of the means in cultivating culture and defending oneself from foreign cultures that are not good and are not in accordance with the customs and cultures that exist in the area.

Thus, exploring and applying the values of local wisdom through education is an effort that can be taken to build national character, strengthen national identity and as a filter for the selection of foreign cultures that are increasingly hitting almost all aspects of life. The same thing is expressed by Sumardjo (2011: 272) that "local wisdom is the best values which are the social norms of the community, local wisdom means the ethics of the community." Therefore, the loss or fading of the local genius means the 
waning of the personality of a society, while the strength of the local genius to survive and develop shows the personality of the community.

From the above explanation, it can be concluded that the values of local wisdom are the views of life that are inherent in the order of community life to protect and manage the environment in a sustainable manner. In protecting and managing the environment in a sustainable manner, the people of Kasepuhan Ciptagelar have knowledge in processing nature that has been passed down from generation to generation from their ancestors. The form is the knowledge of farming and cultivating. For members of the Kasepuhan Ciptagelar community, farming is not only a means of livelihood or a daily routine activity, but believes in it as an obligation to carry on the traditions of their ancestors. This knowledge becomes a provision in maintaining the balance of human life and the natural environment and becomes a provision in living their social life. Thus, it is clear that Seren Taun which is a series of customs in the farming culture in Kasepuhan Ciptagelar has a very meaningful function, namely to fulfill needs that cannot be separated from a dynamic process of change towards the construction of values that have been mutually agreed upon for the life of the supporting community.

\section{Seren Taun Traditional Ceremony}

Etymologically, traditional ceremonies are divided into two words, namely ceremony and traditional. A ceremony is a series of activities carried out by a group of people who have certain rules according to their goals. Whereas what is meant by traditional or custom is an ideal form of culture that functions as a behavior regulation. In the Big Indonesian Dictionary custom, namely various rules (actions and so on) that are commonly carried out since time immemorial, ways of behaving that have become habits, forms of cultural ideas consisting of cultural values, norms, laws and rules which are related to one another a system.

The traditional ceremony is one of the traditional community traditions that is still adhered to and is considered to have values that are still quite relevant to the needs of the community. Traditional ceremonies are closely related to religious rituals. The religious rituals carried out by the community are of course based on the beliefs held by the people. Beliefs like this are what encourage people to perform various actions or behavior that aim to find a relationship with the supernatural world, the Ruler of nature, through religious rituals or other rituals. Apart from being a human effort to be able to relate to the spirits of the ancestors, traditional ceremonies are also a manifestation of human ability to actively adapt to nature or the environment. The relationship between nature and humans is a necessity that cannot be denied, because this relationship has very high sacred values.

Traditional ceremonies are one of the characteristics and forms of existence of a culture. Traditional ceremonies also show us the awareness of cultural identity wrapped in the belief of the cultural community as something of sacred value because it is bound by certain rules based on customs, religion, or belief. Traditional ceremonies cannot even be separated from historical elements because the ceremony is basically a form of community behavior that shows awareness of the past in addition to showing traces of past civilizations. The definition of traditional ceremonies according to Koentjaraningrat (1980: 140) is: Ceremony is an activity or series of actions that are regulated by custom or law that applies in society that is related to various kinds of permanent events that usually occur in the community concerned.

Seren Taun traditional ceremony. The Seren Taun traditional ceremony is one of the traditions owned by the Sundanese agrarian community as an expression of gratitude for God's abundant gift through fertile land and abundant yields. Another example is the people of Palabuhanratu, Sukabumi Regency who live on the coast, they carry out the Labuh Saji traditional ceremony. The Labuh Saji traditional ceremony is a hereditary tradition of fishermen from Palabuhanratu to pay tribute to a princess named Nyi Putri Mayangsagara for her concern for the welfare of fishermen. There are still many other examples relating to the implementation of traditional ceremonies in accordance with events that usually occur in certain community groups. Thus, each region will have different forms of traditional ceremonies due to different customs, social conditions and the environment in which they live.

From the description of the meaning of the Seren Taun traditional ceremony above, it can be concluded that the characteristics of the Seren Taun traditional ceremony are: First, it is carried out by the Sundanese farming community. In the context of the traditional life of the Sundanese farming community, Seren Taun is a means to give thanks to God Almighty for all agricultural products carried out this year, hoping that the farming activities that will be carried out in the future will get safety and an increase in their agricultural products. Second, carried out at the peak of a series of farming activities. The Seren Taun traditional ceremony is the pinnacle of achievement for every individual who has successfully completed the stages in agriculture over a period of one year. Third, the procession of storing seed (pare indung) in the main barn, called the leuit, is carried out. The main thing in the Seren Taun traditional 
ceremony is the procession of storing pare indung in the main barn called the leuit. Therefore, according to ancient Sundanese belief, Seren Taun is a large ceremony as a form of public respect for the ancestor (karuhun) who have inherited rice (pare) as the personification of Sanghyang Nyi Sri Pohaci (Rice Gods) (BPNB, 2012: 155).

\section{Social Studies Teaching Model}

The model is a conceptual framework that is used as a guide in carrying out activities. Meanwhile, teaching is a process that is deliberately designed to create learning activities in individuals. In other words, teaching is something that is external in nature which is deliberately designed to support the internal learning process within the individual (Pribadi, 2009: 17). According to Sagala (2007: 61) "Teaching and learning is a two-way communication, teaching is carried out by the teacher as an educator, while learning is carried out by students or students." Teaching as an arranged combination, includes human elements, materials, facilities, equipment and procedures that influence each other to achieve learning objectives. It is also argued that teaching is an effort to organize an environment to create learning conditions for students.

Social studies (Ilmu Pengetahuan Sosial [IPS]) as an academic study is the development of knowledge related to learning practices. IPS is a study of education and social sciences and humanities for school level education programs. Until now, Social Sciences (IPS) is only an educational program and not a separate sub-discipline, so that it will not be found in the nomenclature of the philosophy of science, social sciences and education. The Social Science Education Council (SSEC) and the National Council for Social Studies (NCSS) call IPS as "Social Science Education" and "Social Studies" or social sciences, because basically social science is no single, but consists of several branches or types such as sociology, anthropology, geography, psychology, economics, political science, law, history and so on (Pargito, 2010: 36).

In connection with the teaching model, Soekamto in Trianto (2009: 74) argues that: Teaching models are conceptual which describe and depict systematic procedures in organizing teaching and learning experiences to achieve certain learning objectives and serve as guidelines for teaching planning for teachers in implementing teaching activities.

Meanwhile, Joyce \& Weil (1980) in Rusman (2012: 133) argues that 'A teaching model is a plan or pattern that can be used to form a curriculum (long-term teaching plan), design teaching materials and guide teaching in classroom or other place'. Thus, the teacher can design an appropriate and efficient learning model to achieve learning objectives as the concept of learning models according to Trianto (2010: 51) which states that "The teaching model is a plan or pattern that is used as a guide in planning classroom teaching or tutorial teaching." The teaching model refers to the teaching approach that will be used, including teaching objectives, stages in teaching activities, teaching environment, and class management. Thus, it can be defined that the teaching model is a systematic procedure or pattern that is used as a guide to achieve learning objectives in which there are strategies, techniques, methods, materials, media and learning assessment tools.

According to Trianto (2010: 53) the function of the teaching model is "As a guide for teaching designers and teachers in implementing teaching." To choose this model is strongly influenced by the nature of the material to be taught, and is also influenced by the objectives to be achieved in the teaching and the level of ability of students. In addition, each teaching model also has stages (syntax) that students can do with teacher guidance. Between one syntax and another syntax also has differences. These differences, including the opening and closing of teaching that are different from one another. Therefore, teachers need to master and be able to apply various teaching skills, in order to achieve the various learning objectives and learning environments that characterize schools today.

In relation to the social studies subject which aims to develop the potential of students to be sensitive to social problems that occur in society, have a positive mental attitude towards correcting all imbalances that occur, and are skilled at overcoming any problems that occur daily, both that befall themselves and those that occur afflicting people's lives, various studies are needed that lead to increasing the efficiency and effectiveness of services and development as a consequence of an educational innovation. One form of efficiency and effectiveness of curriculum implementation, it is necessary to develop various teaching models.

Teaching will get satisfactory results if supported by several factors. One of them is the selection of a teaching model that is tailored to the subject, teaching material, and the development of the students themselves. According to Wahab (2015: 54) the teaching model has the following characteristics: First, it has a systematic procedure. A teaching model must have a systematic procedure for modifying the behavior of students based on certain assumptions. Second, learning outcomes are determined specifically. Each teaching model determines specific learning outcomes that are expected to be achieved 
by students in detail in the form of observable performance. Third, special environmental designation. Specifying environmental conditions specifically in the teaching model. Fourth, have a certain measure of success. The teaching model must determine the criteria for the success of a performance expected of students. Fifth, interaction with the environment, each teaching model establishes a way that allows students to interact and react with their environment.

\section{Ethnopedagogy}

Ethnopedagogy comes from two ancient Greek words, ethnos which means knowledge and the word paidagogeo which means "to guide" literally means to guide children. The word related to pedagogy, namely education, is now used to refer to the entire context of learning, learning, and various activities related to it. Thus, ethnopedology can be interpreted as a science of education in the community.

The role of the world of education is very important in overcoming social problems. Exploring and applying local wisdom values through education is an effort that can be taken to build national character, strengthen national identity and serve as a filter for the selection of foreign cultures that are increasingly impacting almost all aspects of life. As stated by Kartadinata (in his introduction to the Ethnopedagogy Book by Alwasilah et al, 2009) that "We have always been dazzled by the Western education system, so we are blind to local excellence that has long been buried in the earth of Indonesian culture." Then UPI responded with the idea, namely ethnopedagogy. Ethnopedagogy is a practice of education based on local wisdom. Still according to Alwasilah et al (2009: 69) that "Education based on local wisdom through ethnopedagogy will provide meaningful enrichment to support the goals of national education which identifies Indonesia." The same thing was expressed by Sumardjo (2011: 275) that "ethnopedagogy is re-building the continuity of the past and present in certain locales and ethnicities in Indonesia, and the result is for national welfare." Thus, the integration of local wisdom values in education will help shape the character of students who are virtuous and respectful its own culture, foster a love of the country and proud of his identity as the Indonesian nation.

According to Alwasilah et al (2009: 50), ethnopedagogy is "the practice of education based on local wisdom in various domains such as medicine, martial arts, environment, agriculture, economy, government, calendar systems, and others." Ethnopedagogy views local knowledge or wisdom as a source of innovation and skills that can be empowered for the welfare of society. Local wisdom is a collection of facts, concepts of belief, and people's perceptions of the world around them, solving problems, and validating information. In short, local wisdom is how knowledge is generated, stored, applied, managed, and passed on.

Social studies subjects aim to develop the potential of students to be sensitive to social problems that occur in society, have a positive mental attitude towards correcting any imbalances that occur, and are skilled at overcoming any problems that occur daily, both that befall themselves and those that afflict people's lives. In its implementation, it is necessary to carry out various studies that aim at increasing the efficiency and effectiveness of services and development as a consequence of an educational innovation. One form of efficiency and effectiveness of curriculum implementation, it is necessary to develop various models of learning curriculum for local wisdom values at the Seren Taun traditional ceremony in Kasepuhan Ciptagelar as a social study learning model using the ethnopedagogical method.

Ethnopedagogy is a foundation in education as it is in line with one of the foundations of the 2013 curriculum development philosophy, namely education is rooted in the current and future national culture (Ministerial Regulation No. 69/2013). In line with this, Alwasilah et al (2009: 50) state that ethnopedagogy is "the practice of education based on local wisdom in various domains such as medicine, martial arts, the environment, agriculture, economy, government, the calendar system, and others." Ethnopedagogy is an actualization of learning that is oriented towards cultivating local wisdom values. As an approach, ethnopedagogy in schools needs to be implemented with strategies and innovative learning media that can attract students' attention to understand and apply local wisdom.

From the explanation above, it can be concluded that the main characteristic of education through the ethnopedagogical approach is the practice of education based on local wisdom. Because ethnopedagogy views local knowledge or wisdom as a source of innovation and skills that can be empowered for the welfare of society. Local wisdom is a collection of facts, concepts of belief, and people's perceptions of the world around them, solving problems, and validating information. In short, local wisdom is how knowledge is generated, stored, applied, managed, and passed on. The uniqueness of ethnopedagogy which focuses on the values of local wisdom includes the elaboration of the elements, feature and characteristics of local wisdom values which are expected to become a medium for achieving educational goals so that they can be used as a socio-cultural foundation for the benefit of national education. 


\section{RESEARCH METHODS}

The object of research is something that is of concern in a study, the object of this research is the target in research to get answers and solutions to problems that occur. According to Sugiyono (2009: 38) the object of research is "An attribute or characteristic or value of people, objects or activities that have certain variations that are determined by the researcher to be studied and then draw conclusions." Sugiyono (2017: 41) explains that the definition of the object of research is "Scientific goals to obtain data with specific purposes and uses about something objective, valid and reliable about a thing (certain variables)." The research objects that the writer studied were local wisdom values, Seren Taun traditional ceremonies in Kasepuhan Ciptagelar, ethnopedagogy, and social studies teaching models.

The first research to identify local wisdom values Seren Taun traditional ceremony was conducted in Kasepuhan Ciptagelar traditional village, which is in Sukamulya Hamlet RT 02 RW 07 Sirnaresmi Village, Cisolok District, Sukabumi Regency. Kasepuhan Ciptagelar is $14 \mathrm{Km}$ away from Sirnaresmi Village, $28 \mathrm{Km}$ away from the sub-district town, $32 \mathrm{Km}$ from the government center of Sukabumi Regency and $180 \mathrm{Km}$ from Bandung to the west, located between the valley of the Halimun mountains. Furthermore, the research was carried out at Public Junior High School I (SMPN I) Nagrak, Nagrak District, Sukabumi Regency to design social studies teaching, carry out the process of teaching activities and apply social studies teaching by integrating local wisdom values at the Seren Taun traditional ceremony at Kasepuhan Ciptagelar into social studies teaching at SMPN I Nagrak as an ethnopedagogy teaching model.

For research to identify the values of local wisdom, the Seren Taun traditional ceremony is carried out on two ceremonies of Seren Taun which are followed from preparation to the implementation of the Seren Taun celebration, namely the $650^{\text {th }}$ Seren Taun traditional ceremony which falls on 7 to 9 September 2018 and the $651^{\text {st }}$ Seren Taun traditional ceremony on 6 to 8 September 2019. Meanwhile, research at Nagrak Junior High School was conducted from November 2019 to February 2020.

Kasepuhan residents are indigenous people who rely on rice cultivation. So, the livelihoods of the people of the Kasepuhan Ciptagelar Traditional Village are mostly as farmers. Agriculture plays a very important function for the existence and survival of the Kasepuhan Ciptagelar community. For the Ciptagelar Indigenous People, farming is an obligation of their life. Each Kasepuhan resident has at least their own rice fields and barns. As the peak of farming activities, the Seren Taun traditional ceremony is carried out as a means of thanking God Almighty for all agricultural products carried out this year, hoping that the farming activities that will be carried out in the future will get safety and an increase in their agricultural products. In the Seren Taun traditional ceremony, there is a meaning that contains local wisdom values. Based on the explanation above, the writer is interested in digging deeper into the values of local wisdom contained in the Seren Taun traditional ceremony at Kasepuhan Ciptagelar to be integrated into social studies as an ethnopedagogy teaching model at SMPN I Nagrak.

In this study the authors used a qualitative approach. This is because the qualitative approach is more in-depth about human problems as a research instrument. The methods of interviewing, observing and documenting and analyzing techniques are dominant about the existence of human behavior such as listening, seeing, talking and interacting. by using data collection techniques such as observation, interviews, documentation and triangulation. The data analysis technique starts with data reduction, data presentation and data verification (conclusion).

\section{DISCUSSION RESULT}

1. Forms of Local Wisdom Values for the Seren Taun Kasepuhan Ciptagelar Traditional Ceremony which can be Integrated into Social Studies Subjects at SMPN 1 Nagrak.

Indonesia is a country with rich ethnic groups, each of which has a culture as their ethnic identity. The Indonesian nation has many cultures that inherent in everyday life which have been preserved from generation to generation, especially in the lives of indigenous peoples. One form of culture is local wisdom. Local wisdom is a value system or life behavior of local people in interacting wisely with the environment in which they live. Local wisdom means the ethics of a society which are the social values of the community. The indigenous peoples who still exist today are scattered in various regions in Indonesia, one of which is the Kasepuhan Ciptagelar indigenous people, namely groups of people who still adhere to the cultural heritage of their ancestors in carrying out their daily lives, especially in farming procedures. The agricultural system in Kasepuhan Ciptagelar still uses the traditional system. Kasepuhan Ciptagelar community members have knowledge and skills in farming, cultivating crops and cultivating nature, whose knowledge has been passed down from generation to generation from their ancestors. This knowledge becomes a provision in living their social life, because most of them spend their daily time in the lea or in the rice fields. And at its peak when the harvest time 
or Seren Taun comes, this Seren Taun has its own function and meaning which is contained in the symbols.

Referring to the structural theory of semiotics, which is the study of signs in human life, in the sense that everything in human life can be seen as a sign, that is, something that we must give meaning. So, from the explanation of the symbols used by the Kasepuhan Ciptagelar community, it is clear that the values of local wisdom in the Seren Taun traditional ceremony in Kasepuhan Ciptagelar are found in the meanings in traditional expressions and proverbs. This is a sign consisting of: a penanda (words in a traditional expression) and a petanda (the meaning contained in the expression). Referring to the hermeneutic theory which contains an understanding directed at the traditional context of meaning, it is clear that the meaning contained in each symbol contained in the Seren Taun traditional ceremony is interpreted to be used as a guide in carrying out daily life. Hermeneutics is seen as a rule used to interpret meanings and symbols in works of art and literature. Hermeneutics as a theory of reflective interpretation is based on philosophical phenomenology. Hermeneutics views culture as a system of meaning which is considered a kind of storage place for the collective memory of a group of people. Likewise, in local wisdom which is part of culture, full of the meaning of each symbol that is believed to be true so that it becomes a guide in living life.

2. Compilation of Social Studies Teaching Plans by Integrating the Values of Local Wisdom in the Seren Taun Kasepuhan Ciptagelar Traditional Ceremony

Social studies learning as an academic study is the development of knowledge related to learning practices. IPS is a study of education and social studies and humanities for school level education programs. Learning will get satisfactory results if supported by several factors. One of them is the development of a syllabus and lesson plans using a learning model that is tailored to the subject, teaching material, and the development of the students themselves. Creative teachers will present a variety of learning models. In addition to taking learning resources from source books, the surrounding environment can also be used as a learning resource. Lots of things that can be used as learning materials for social studies subjects that come from the surrounding environment, including natural potential, local wisdom, arts, livelihoods, government institutions, traditional institutions, kinship systems, and many more that can be used as IPS's learning materials. However, there are still many teachers who do not use the surrounding environment as learning material. They are only fixated on the source book. This will affect learning activities which only transfer information from source books. So that the learning objectives cannot be achieved optimally.

3. Implementation of Social Studies Learning Process by Integrating the Values of Local Wisdom in the Seren Taun Kasepuhan Ciptagelar Traditional Ceremony as an Ethnopedagogical Teaching Model

Social studies subjects aim to develop the potential of students to be sensitive to social problems that occur in society, have a positive mental attitude towards correcting any imbalances that occur, and are skilled at overcoming any problems that occur daily, both that befall themselves and those that afflict people's lives. In its implementation, it is necessary to carry out various studies that aim at increasing the efficiency and effectiveness of services and development as a consequence of an educational innovation. One form of efficiency and effectiveness of curriculum implementation, it is necessary to develop various models of learning curriculum for local wisdom values.

Education that is associated with the culture of the community should be used as a guide for educators in finding alternative solutions for solving the problem of the erosion of national identity for the younger generation. But unfortunately, in current educational practice there is a tendency for inconsistencies between the educational process and cultural existence. Whereas cultural aspects should serve as guidelines for every implementation of education. With the occurrence of a phenomenon like this, it is necessary to reorient the education process so that in its implementation it always considers elements of local culture in order to strengthen national identity and foster a love for culture for the nation's future generations.

Ethnopedagogy is a foundation in education as it is in line with one of the foundations of the 2013 curriculum development philosophy, namely education is rooted in the culture of the present and future (ministerial regulation No. 69 of 2013). Ethnopedagogy is an actualization of learning that is oriented towards cultivating local wisdom values. As an approach, ethnopedagogy in schools needs to be implemented with strategies and innovative learning media that can attract students' attention to understand and apply local wisdom. The uniqueness of ethnopedagogy which focuses on the values of local wisdom includes the elaboration of the elements, characteristics and characteristics of local wisdom values which are expected to become a medium for achieving educational goals so that they can be used as a socio-cultural foundation for the benefit of national education.

In Frederich Barth's Theory of Ethnicity, ethnopedagogy views local knowledge or wisdom as a source of innovation and skills that can be empowered for the welfare of society. Local wisdom is a 
collection of facts, concepts of belief, and people's perceptions of the world around them, solving problems, and validating information. Ethnopedagogy is closely related to ethnicity theory. According to Alwasilah et al (2009: 50) that ethnopedagogy is 'the practice of education based on local wisdom in various domains such as medicine, martial arts, the environment, agriculture, economy, government, calendar systems, etc.' Ethnopedagogy views knowledge or local wisdom as a source of innovation and skills that can be empowered for the welfare of the community. In short, local wisdom is how knowledge is generated, stored, applied, managed, and passed on. So ethnopedagogy can be interpreted as the science of education within the community, while ethnicity itself in Frederich Barth's view refers to a certain group which due to the similarity of race, religion, national origin, or a combination of these categories is tied to its cultural value system. From the explanation above, it can be concluded that ethnopedagogy is a deeper development of the ethnicity theory. Ethnopedagogy explores the treasures of local wisdom that have grown from generation to generation in an ethnic group to support national education by building education that identifies Indonesia with diverse cultural potentials but has a unified aspiration to build a dignified nation through education.

\section{CONCLUSION}

Based on the results of the research and discussion in the previous description, it can be concluded as follows: First, the form of local wisdom values contained in the Seren Taun traditional ceremony in Kasepuhan Ciptagelar which can be integrated into the social studies subject is Ngajagi Tatali Paranti Karuhun (Religious Values), Nincak Kana Tatanan (Value of Compliance), Nangtung di kariungan ngadeg di karamean (Value of Mutual Cooperation), Gunung luhur kayuan, lamping gawir awian, legok balongan, lebak kulahan, datar sawahan (Value of natural resource preservation), Saiketan Sabeungkeutan (Value of Unity and Oneness), Kudu bisa ngigelan jaman tapi ulah kabawa ku jaman (Value Balance Between Tradition and Modernization). These values are shown by the people of Kasepuhan Ciptagelar in a series of traditional Seren Taun ceremonies. The values contained in the Seren Taun traditional ceremony can be used as teaching for students by integrating them into social studies subjects. Second, the integration of local wisdom values contained in the Seren Taun traditional ceremony in Kasepuhan Ciptagelar in social studies teaching includes planning and implementing teaching activities. Planning activities include the development of a syllabus and the development of a Learning Implementation Plan (RPP) as well as the preparation of learning strategies based on local wisdom values contained in the Seren Taun traditional ceremony in Kasepuhan Ciptagelar. The teaching implementation is carried out through the ethnopedagogy teaching model by integrating the values of the Seren Taun traditional ceremony. The implementation of teaching includes preliminary activities (orientation, perception, motivation and reference), core activities (the teaching process to achieve Core Competencies, Basic Competencies and indicators of achievement of learning outcomes) and closing activities (conclusions, reflections, moral messages, assignments). Teaching media with video viewing of the Seren Taun traditional ceremony. Teaching strategy by singing Sundanese songs, Sundanese greeting communication practices, and playing BUMOSI (Buah Informasi/ fruit of information). In this game, students are required to be able to collect as much information as possible from the material that has been observed, namely video viewing and from the teacher's explanation written on fruit-shaped colored paper which is then attached to a tree image prepared by the teacher who previously had to take the leaf-shaped paper first which contains orders to play a game, pupuh and kakawihan songs. Therefore students must be careful in listening to and observing the learning material. The more information collected, the more fruit that is attached means the higher the level of understanding of the students. In theory, they are able to achieve Basic Competence (KD) and indicators of achievement of learning outcomes and at the same time can implement the values contained in the Seren Taun Kasepuhan Ciptagelar traditional ceremony during the learning process. Third, the implementation of social studies learning with an ethnopedagogical model that integrates the values of local wisdom of the Seren Taun traditional ceremony is able to attract the attention of students in understanding the values of local wisdom as national identity. Ethnopedagogical models will be more effective if implemented with innovative strategies and learning media. The actualization of learning that is oriented towards the cultivation of local wisdom values followed by playing, singing and other practical activities can create active, creative, effective, and fun learning. In addition, learning based on the values of local wisdom can foster a love for the nation's culture.

The recommendations presented are as follows: First, for the school concerned and other educational institutions: The integration of local wisdom values in learning is highly dependent on the creativity of teachers in developing syllabus and Learning Implementation Plans (RPP) as well as accuracy in selecting strategies and media learning. Social studies teachers must broaden their insights and knowledge in exploring local wisdom in the local environment so that the values contained in local 
wisdom can be integrated into learning. Besides being able to create an active, creative, effective, and fun learning atmosphere, it can also foster students' love for the nation's culture. This can be one of the strongholds to protect the national identity of students amid the swift currents of globalization. The effectiveness of integrating the values of local wisdom in learning also very much depends on the roles and responsibilities of all components in the school and the participation of parents at home. Therefore, the role of all parties must be increased in providing examples to students about the importance of local wisdom values. Second, the government, in this case the Culture, Youth and Sports Office of Sukabumi Regency, can collaborate with the Sukabumi Regency Education Office in carrying out the mandate of Law No. 5 of 2007 concerning the promotion of culture by implementing four strategic steps namely protection, development, utilization and cultural fostering in Kasepuhan, Ciptagelar. The Law on the Advancement of Culture recognizes and respects the diversity of Indonesian culture, places the community as the owner and activator of culture, and places culture as the direction of national development which includes the development of Indonesia's human resources. The local wisdom of the Seren Taun traditional ceremony is a cultural treasure that contains very noble social values that we must appreciate and integrate in social studies learning can strengthen the national identity of students as an effort to build quality and character Indonesian human resources.

\section{REFERENCES}

Anwar \& Adang, (2017). Sosiologi. Bandung: PT. Refika Aditama

Alwasilah, et al. (2009). Etnopedagogi Landasan Praktek Pendidikan dan Pendidikan Guru. Bandung: PT. Kiblat Buku Utama.

A. Pribadi, Benny. (2009). Model Desain Sistem Pembelajaran. Jakarta: PT Dian Rakyat.

Balai Pelestarian Nilai Budaya Bandung, (2012). Upacara Seren Taun pada Masyarakat Kasepuhan Ciptagelar Sukabumi. Bandung.

Hamdani, A. R. et al. (2017). Etnopedagogik Kearifan Lokal Sebagai Landasan Pendidikan. Bandung: ALFABETA.

Koentjaraningrat, (2014). Sejarah Teori Antropologi I. Jakarta: UI Press.

Koentjaraningrat, (2015). Sejarah Teori Antropologi II. Jakarta: UI Press.

Komara, E. (2019). Teori Sosiologi dan Antropologi. Bandung: Refika Aditama.

Rohaedi, (1986). Kepribadian Budaya Bangsa (Local Genius). Jakarta: PT. Dunia Pustaka Jaya.

Rusman, (2012). Model-model Pembelajaran. Jakarta: PT Rajagrafindo Persada.

Sagala, Syaiful. (2007). Konsep dan Makna Pembelajaran. Bandung: CV. ALFABETA.

Sugiyono. (2009). Metode Penelitian Kuantitatif Kualitatif, dan R \& D. Bandung: Alfabeta.

Sugiyono. (2012). Metode Penelitian Kuantitatif, Kualitatif dan R\&D. Bandung: Alfabeta.

Sulasman, \& Setia Gumilar. (2018). Teori-teori Kebudayaan : Dari Teori hingga Aplikasi. Bandung: Pustaka Setia.

Sumardjo, J. (2011). Hermeneutika Sunda. Simbol-simbol Babad Pakuan/Guru Gantangan. Bandung: Kelir.

Balai Pelestarian Nilai Budaya Bandung, (2012). Upacara Seren Taun pada Masyarakat Kasepuhan Ciptagelar Sukabumi. Bandung.

Hamdani, A. R. et al. (2017). Etnopedagogik Kearifan Lokal Sebagai Landasan Pendidikan. Bandung: ALFABETA.

Koentjaraningrat, (2014). Sejarah Teori Antropologi I. Jakarta: UI Press.

Koentjaraningrat, (2015). Sejarah Teori Antropologi II. Jakarta: UI Press.

Komara, E. (2019). Teori Sosiologi dan Antropologi. Bandung: Refika Aditama.

Rohaedi, (1986). Kepribadian Budaya Bangsa (Local Genius). Jakarta: PT. Dunia Pustaka Jaya.

Rusman, (2012). Model-model Pembelajaran. Jakarta: PT Rajagrafindo Persada.

Sagala, Syaiful. (2007). Konsep dan Makna Pembelajaran. Bandung: CV. ALFABETA.

Sugiyono. (2009). Metode Penelitian Kuantitatif Kualitatif, dan R \& D. Bandung: Alfabeta.

Sugiyono. (2012). Metode Penelitian Kuantitatif, Kualitatif dan R\&D. Bandung: Alfabeta.

Sulasman, \& Setia Gumilar. (2018). Teori-teori Kebudayaan : Dari Teori hingga Aplikasi. Bandung: Pustaka Setia.

Sumardjo, J. (2011). Hermeneutika Sunda. Simbol-simbol Babad Pakuan/Guru Gantangan. Bandung: Kelir. Somantri,N, et al (2010). Inovasi Pembelajaran IPS. Bandung : Rizqi Press.

Trianto (2009).Mendesain Model Pembelajaran Inovatif Progresif .Surabaya: Kencana

Trianto (2010) Model Pembelajaran Terpadu. Surabaya: Bumi Aksara

Wahab, (2017). Metode dan Model-model Mengajar. Bandung: Alfabeta 